\title{
To Teach or not to Teach: The Politics of Becoming a Business Education Teacher.
}

\author{
Burman M. Sithole, University of Botswana
}

\begin{abstract}
This article examined the perceptions and attitudes of Business Education trainee teachers towards teaching as an employment option in life. The findings revealed that business graduates were reluctant to take up teaching as a career mostly because it was not viewed as a financially rewarding profession. Students had expectations of landing higher status and highly paying jobs in commerce, industry and the public sectors. They felt that the knowledge and skills they acquired in undergraduate business courses would not be fully utilised in teaching. To attract graduates to teaching, competitive salaries and conditions of service would need to be put in place and there is need by educators to market teaching and elevate its status as a career option when outlining career opportunities to business students.
\end{abstract}

\section{Introduction}

Business Education is about preparing students for career options within business and preparing them to handle their own business affairs as well as to enable them to function intelligently as consumers. It is provided to meet both general education and career and technical needs of students in order to prepare them for careers in business as well as to help them to assume their economic roles as consumers, workers and citizens (Calhoun \& Robinson, 1995). Examples of subjects that fall under the Business Education curriculum in schools include Accounting, Commerce, Business Studies, Management of Business and Economics.

A challenge that has faced many schools is the shortage of Business Education teachers (Lambrecht, 2002). One of the major causes of the shortage of these teachers is the fact that young business graduates who qualify from universities and other institutions of higher learning opt to fill financial positions in commerce and industry simply because salaries of teachers are not competitive in the market (Graig 2008). This is supported by Thomas (2007) who said that a major challenge facing the delivery of Business Education in schools is that methodologically trained teachers in business and other technical fields are scarce because they can easily get higher status jobs in commerce and industry. There also exists intense competition from the corporate world which makes it difficult for schools to recruit teachers into disciplines such as Accounting (Pitts, 2007). High salaries and lots of intangible benefits would need to be paid to entice them into the teaching field.

To attract college and university graduates to teaching, it is necessary that teachers' salaries keep pace with other professions that are luring teachers from the classroom. It is common knowledge that salaries of teachers are not competitive enough. There is evidence that teachers are more likely to quit when their salaries are low compared 
to alternative job opportunities (Baugh \& Stone, 1982). It is said that the effects of wage differentials are strongest at the start of the teaching career (Hanushek, Kain \& Rivkin, 1999) and this is when it is critical to try and retain beginning Business Education teachers. Teachers in high demand areas are especially vulnerable to salary differences in their decisions to remain in teaching (Murnane \& Olsen, 1990).

It should also be borne in mind that despite some of the factors cited above, business students may be reluctant to join the profession because teaching is generally perceived as a low-status job. Studies in sub-Saharan Africa, and indeed the world over, have shown that the teaching profession is generally looked down upon because of perceived low remuneration and generally poor conditions of service (Chivore, 1988; Towse, Kent, Osaki \& Kirua, 2002) such as arbitrary teacher deployment systems, unattractive work locations, lack of professional development appointments and insufficient supportive supervision (Mulkeen, Chapman, DeJaeghere, Leu \& Bryner, 2005).

In light of the above, it is critical that the number of business graduates choosing to become teachers be expanded and that those beginning teachers of business subjects who opt to remain in classrooms be increased and retained. It was against this background that this study sought to find out Business Education student teachers' views and perceptions with regard to pursuing teaching as a career. These were the research questions: Why do business graduates pursue studies in education? What are their perceptions towards the teaching profession? To what extent do they consider teaching as a lifelong career?

\section{Methodology}

The study used a descriptive survey design. The subjects were 17 Business Education students enrolled in the Postgraduate Diploma in Education (PGDE) programme at the University of Botswana in Semester 2 in 2008. The 17 (B1, B2, B3, .., and B17) were part of a class of 20 and they participated in the study by virtue of their willingness to take part in it and their being present on the day the questionnaire was administered.

Nine items of 16-item questionnaire adapted from Kamwendo and Moumakwa (2005) were used to collect data from the respondents. They elicited information on respondents' teaching experience(s) before enrolling in the PGDE programme, what they majored in, in their undergraduate studies, why they enrolled in PGDE and information on their future aspirations. Semi-structured interviews were conducted with 4 students (Bi, Bii, Biii and Biv) who were selected using purposeful sampling. Data on why they enrolled in the PGDE programme and their views and perceptions on teaching as a career were sought and triangulated with survey data.

\section{Results and Discussion}

Of the 17 respondents, 9 held degrees in Accounting, 7 in Business Administration (with majors in Marketing, Management or Human Resource Management) and 1 in Economics. All 17 had hoped to find jobs in commerce, industry and the public sectors as accountants, financial analysts, human resources officers, in marketing and supply management. None had teaching in mind. $16(94.1 \%)$ of the respondents 
joined the PGDE programme because they had failed to secure jobs of their choice and $12(70.6 \%)$ indicated that they were still actively seeking employment. Responses to closed items are summarised in Table 1 below:

Table 1: Students' responses and attitudes towards teaching.

\begin{tabular}{|l|c|c|c|c|}
\hline \multirow{2}{*}{ Item } & \multicolumn{2}{|c|}{ Yes } & \multicolumn{2}{c|}{ No } \\
\cline { 2 - 5 } & $\mathbf{n}$ & $\mathbf{\%}$ & $\mathbf{n}$ & $\mathbf{\%}$ \\
\hline Do you have any teaching experience? & 2 & 11.8 & 15 & 88.2 \\
Was teaching your intended career? & 0 & 0.0 & 17 & 100.0 \\
If you were to find a job now, would you & 12 & 70.6 & 5 & 29.4 \\
withdraw from the PGDE programme? & & & & \\
\hline $\begin{array}{l}\text { Do you intend to remain a teacher on } \\
\text { completing your training? }\end{array}$ & 6 & 35.3 & 11 & 64.7 \\
\hline
\end{tabular}

The findings presented in Table1 suggest that the majority of business graduates who enrol for teacher training do so as a last resort. Having failed to pursue their first choice careers, they had to find an alternative and ended up enrolling in the PGDE programme. None of the respondents had considered teaching as a career and most were prepared to withdraw from the programme should attractive employment opportunities arise. To some enrolling in the PGDE programme was some sort of stopgap measure while they actively sought employment. This was confirmed in interview and questionnaire responses:

B3: "I do not like teaching".

B14: "Teaching is my last resort".

Bi: "I only joined PGDE because I had nothing to do. If I find a job I will leave. Most of us are busy looking for jobs right now".

Biv: "I never wanted to be a teacher. I would rather have an office job as an accountant".

B16: "After all I want to become an accountant so if I get the opportunity I forget about teaching".

The lack of enthusiasm is not surprising at all. Teachers are generally looked down upon by people including their students, which makes the job unattractive. It explains why trainee teachers appear not to be particularly enthusiastic about teacher education (Awanbor, 1996 cited in Osunde \& Izevbigie, 2006). It is up to business teacher educators to wrestle with students' negative preconceived beliefs about the teaching profession. Teaching can be a rewarding career for business graduates who really want to make a difference preparing young people for employment and economic citizenship while working outside office-based environments.

Another factor cited by the respondents for not wanting to be teachers was a perceived mismatch between the skills required in teaching and what the students had done in their undergraduate work. Students appeared to want to avoid one form of 
what economists call underemployment, a situation where one works a job for which they were not trained. The general perception was that joining teaching would result in them not fully utilising the business training they had received.

B10: "I want to do my job that I trained for (sic) but I will find a way of using my PGDE knowledge and skills".

B9: "Why would I waste the qualification I have?"

B12: "Because I don't like teaching and it is a waste of time and not challenging".

B4: "I want to become a financial analyst or follow up any career related to finance because I really love that. That's where my passion falls".

Underemployment is the employment of workers with high skill levels in low-wage jobs that do not require such abilities. Business teacher trainees believed that there existed a mismatch between the skills they had acquired in business school relative to those that are required in teaching. If such students were to subsequently join the teaching profession, they would be "discouraged" worker, which represents a serious type of underemployment. What business teacher trainees should bear in mind is the fact that the $30+$ courses they studied in their undergraduate work will not necessarily be put to waste in teaching. On the contrary, their deep understanding of business subject matter content would be invaluable in teaching. Possession of this kind of understanding provides a foundation for pedagogical content knowledge that would enable them to impart business knowledge to others (Gudmundsdottir \& Shulman, 1987). Furthermore, landing jobs in the private sector will not guarantee that they will fully utilise their training. Studies in Europe have shown that one in four graduates' skills were insufficiently used in the workplace (Marshall, 2008) and it is not uncommon for business graduates to take up jobs that have no relevance to their studies.

The issue of low remuneration as one of the factors contributing to the reluctance by many people to join the teaching profession has been raised in many forums and respondents in this study were no exception.

B13: "I do not have a passion for teaching and it's one of the lowest paying jobs. I am a capitalist".

B17: "Teaching environments are not conducive, poor salary, no improvement".

These findings confirmed what has already been documented in the literature that business graduates who qualify from universities and institutions of higher learning opt to fill positions in commerce and industry simply because of higher salaries and higher status posts offered there (see Thomas, 2007; Graig 2008). It is common knowledge that if people hope to become rich through a teaching career they will be pursuing the wrong profession but if they are looking for a profession that is intellectually stimulating and rewarding and carries a decent wage, then the place to look for is teaching. 
According to Lambrecht (2002), one challenge that faces business teacher education is to provide viable paths for professional development and growth. This is confirmed in this study where some of the respondents pointed out that it was professional growth and progression that mattered and they were of the opinion that this was lacking in teaching:

B6: "There are few opportunities of growing in teaching".

B15: "The teaching profession is slow in terms of progress".

Bii: "I don't want to be stuck in a classroom for the whole of my life (sic). There are no chances of promotion in teaching".

The lack of opportunities to advance within the teaching field is a crucial factor in discouraging people from entering the profession. Public service teaching, like in all bureaucracies has poor career prospects especially when promotion is based on seniority with little regard to meritorious service. There is no denying the fact that because of their large numbers, the upward progression of teachers is slower than that of their counterparts in other economic sectors. There however, are several career paths to pursue in the teaching profession. The opportunities for career progression include running a whole school as a headteacher or one can rise to be a deputy headteacher, senior teacher or taking responsibility of a business studies department in a school. There are also prospects of taking up teaching posts in institutions of higher learning or taking up managerial posts in teaching-related government departments such as curriculum development, examinations and school inspectorates.

Although a large number of reluctant trainees remained reluctant, it was quite heartening to note that there were some students who had been converted. They had stumbled into the PGDE teacher training programme and found themselves falling in love with teaching.

B7: "All of a sudden the field seems so interesting".

B8: "I have researched well on the teaching profession and wouldn't mind being a teacher".

B11: "I have acquired a lot and not becoming a teacher would be wrong for me. I now have the passion".

Biii: "I have always wanted to develop myself academically. I have realised that I can help or assist in the training of fellow Batswana. Teaching and lecturing provide this opportunity".

All hope is not lost. After all teaching can be enormously gratifying and many more people could make it their career choice if attractive financial and non-monetary incentives to reward good teachers are put in place.

\section{Conclusion}

In order to increase teacher supply in general and business education teacher supply in particular, it is critical to expand the number of individuals choosing to become teachers. This can be done if those in authority start to put in place relevant incentives. Teachers desire competitive conditions of service such as small class sizes, better 
teaching and learning resources, supportive supervision and ongoing in-service professional development (Mulkeen, Chapman, DeJaeghere, Leu \& Bryner, 2005). Teachers' conditions of service should be comparable with those found in quasigovernment organisations like parastatals and the private sector. It is critical to retain beginning teachers and to bolster the numbers of teachers in critical areas like Business Education. Business students' attitudes towards teaching need to be improved. They must be re-oriented on the dignity of teaching and the career options it affords. When outlining career opportunities to such students, educators must not only talk of private and non-teaching public sector employment opportunities; they must also market teaching as a potentially fulfilling and rewarding field. If we don't do this, the future shortage of these teachers may come back to haunt us.

\section{References}

Baugh, W.H., \& Stone, J.A. (1982). Mobility and wage equilibration in the educator labor market. Economics of Education Review, 2 (3): 253-274. http://www.mmegi.bw/index. php?sid=1\&aid=34\&dir=2007/August/Friday31

Calhoun, C. C. \& Robinson, B. W. 1995. Managing the Learning Process in Business Education. Birmingham, AL: Colonial Press.

Chivore, B.R.S. (1988). Factors determining the attractiveness of the teaching profession in Zimbabwe. International Review of Education 34 (1): 59-78.

Graig, A. (2008, 9 Jan). Namibia: Accountant shortage looms for Namibia. The Namibian. Retrieved March 19, 2008 from http://allafrica.com/stories/200801090409.html

Gudmundsdottir, S. \& Shulman, L. (1987). Pedagogical content knowledge in social studies. Scandinavian Journal of Education Research, 31(2):59-70.

Hanushek, E.A., Kain, J.F., \& Rivkin, S.G. (1999). Do higher salaries buy better teachers? Working Paper 7082. Cambridge, MA: National Bureau of Economic Research.

Kamwendo, G. \& T. Moumakwa. (2005). Towards Quality Teacher Education: An Examination of the Strengths and Weaknesses of the University of Botswana's PGDE English Language Programme. Paper presented at the 11th BOLESWANA Symposium, University of Namibia, Windhoek, 6-8 July, 2005.

Lambrecht, J. J. (2002). Business education, preparation of teachers. In Encyclopedia of education (2nd ed.). New York: Macmillan.

Marshall, J. (2008). Europe: Preparing graduates for the workplace. Retrieved July 14, 2008, from http://www.universityworldnews.com/article.php?story=20080711104512192

Mulkeen, A., Chapman, D.W., DeJaeghere, J.G., Leu, E. \& Bryner, K, (2005). Recruiting, Retaining, and Retraining Secondary School Teachers and Principals in Sub-Saharan Africa, Washington: Academy for Educational Development.

Murnane, R.J. and Olsen, R. J. (1990). The effects of salaries and opportunity costs on length of stay in teaching: Evidence from North Carolina. The Journal of Human Resources, 2(1): 106-124.

Osunde, A.U. \& Izevbigie, T.I. (2006). An assessment of teachers' attitude towards the teaching profession in Midwestern Nigeria. Education, Spring 2006. Retrieved June 18, 2008, from http://findarticles.com/p/articles/mi qa3673/is_200604/ai_n17182823

Pitts, G. (2007). Business academics write their own tickets. Retrieved March 19, 2008, from http://license.icopyright.net/user/webEprint.act?id=3.7441-58039

Thomas, T. (1997, Feb 3). Schools learn a lesson of the times. Business Review Weekly, pp. 26-31.

Towse, P., Kent, D., Osaki, F. \& Kirua, N. (2002). Non-graduate teacher recruitment and retention: some factors affecting teacher effectiveness in Tanzania. Teaching and Teacher Education, 18: 637-652. 